\title{
Molecular Identification of the Genus Molicola Larvae from Swordfish (Xiphias gladius) Captured in Sri Lanka by Ribosomal Subunit Gene Sequencing
}

\author{
D.P.N. De Silva ${ }^{1,2 *}$, J.L.C.S. Perera ${ }^{3}$, H.S.D. Fernando ${ }^{1}$, R.R.M.K.P. Ranatunga ${ }^{1}$ and \\ B.G.D.N.K. De Silva ${ }^{1}$ \\ ${ }^{1}$ Center for Biotechnology, Department of Zoology, Faculty of Applied Sciences, University of Sri \\ Jayewardenepura, Nugegoda, Sri Lanka \\ ${ }^{2}$ Department of Animal Science, Faculty of Animal Science and Export Agriculture, Uva Wellassa \\ University, Badulla, Sri Lanka \\ ${ }^{3}$ Laboratory of Veterinary Public Health, Graduate School of Agricultural \& Life Sciences, The \\ University of Tokyo, 1-1-1 Yayoi, Bunkyo-ku, Tokyo 113-8657, Japan
}

*Correspondence :

prasadi@uwu.ac.lk

Received : 2020-07-22

Accepted : 2020-09-05

Keywords :

Molicola, Swordfish, Trypanorhyncha, rRNA

\begin{abstract}
Swordfish (Xiphias gladius) is a migratory fish commercially exploited due to its high export value. The presence of parasites in fish leads to economic losses in the export market and public health issues. This study was conducted to identify the parasite larvae inhabiting swordfish and to determine its phylogenetic origin using ribosomal subunit gene sequence. Parasite samples were extracted from swordfish muscles and five larvae belong to Molicola genus, confirmed by scolex morphology, were used for genomic DNA extraction. Polymerase chain reaction (PCR) was performed to amplify $18 \mathrm{~S}$ and $28 \mathrm{~S}$ ribosomal RNA (rRNA) subunit genes followed by Sanger sequencing. DNA sequences were edited by BioEdit software and assembled by CLC genomics version 8.0. Consensus sequences were aligned with NCBI blast to determine the species status. Isolated larval sequences were best aligned with genus Molicola followed by genus Gymnorhyncha. Out of the two published Molicola rRNA gene sequences, 99\% identity was observed with Molicola sp. HP5 isolate from Indonesia. Due to the lack of sequence data on other Molicola species (except M. thyristes) for comparison, our sequences were published as Molicola sp. Sri Lankan isolates. This is the first record of Molicola sp. in swordfish from Sri Lanka and the results will enhance the knowledge on the distribution of Molicola species while contributing to expanding the genetic information on rRNA coding sequences.
\end{abstract}

\section{INTRODUCTION}

Capture fisheries provide $65 \%$ of the animal protein requirement of the people in Sri Lanka. According to the fisheries statistics in 2016, its contribution to gross domestic production (GDP) was around $1.8 \%$ (marine $1.6 \%$, inland $0.2 \%$ ).
Among food fish Tuna species is the highest catch while swordfish (Xiphias gladius) is one of the seasonal fish which has higher demand from importing countries (Ministry of Fisheries \& Aquatic Resources Development, 2019). Swordfish 
is also called Broadbill, belongs to the family Xiphiidae of order Perciformes. They can be found in the Indian, Atlantic and Pacific oceans as well as in the Mediterranean, Marmara, Black, and Azov seas (FAO, 2019). Due to over-fishing, this species reduced by $28 \%$ over the past two decades (IUCN, 2019). Swordfish migrate to cold waters for feeding and returns to warm waters during summer for spawning. They eat small to relatively large fishes and occasionally consume crustaceans and squids (Williams and Bunkley-Williams, 1996). These feeding and breeding patterns increase their risk of getting exposed to parasites. Most of the marine helminths, especially Trypanorhyncha species have multiple hosts during their life cycle including swordfish and crustaceans as intermediate hosts (Palm and Caira, 2008).

The parasitism in fish is an ecological coexistence between two organisms in close contact. Some parasites establish an equilibrium of host-parasitic relationship being encysted or dormant until it gets a favorable condition to multiply (Schaperclaus, 1992). It is found that there are 49 parasitic species infecting swordfish. About 13 of them are hostspecific while six are super family-specific. Swordfish harbors about 20 larval tapeworm species particularly due to the consumption of intermediate hosts infested with parasitic larvae. There are 14 cestodes (tapeworms) recorded in swordfish including Trypanorhynch (Williams and Bunkley-Williams, 1996).

Parasites infesting swordfish muscles include Pennella sp. (Copepod) (Hogans et al., 1985; Castro-Pampillón et al., 2002), cestode Trypanorhyncha plerocercoid larvae of Molicola (Gymnorhyncus) horridus, and Gymnorhynchus gigas, and flukes, Maccalumtrema xiphiados. A zoonotic parasite Anisakis nematode larvae were also reported in swordfish muscle (Hogans et al., 1983; Castro-Pampillón et al., 2002; Garcia et al., 2011).

In Sri Lanka, swordfish catch is seasonal, and a large amount of flesh was discarded due to parasitic infestation in muscles. A whitish, thread-like parasite found in muscles often mistook as the zoonotic Anisakis species until a preliminary study using morphological evaluation of this parasite revealed as plerocercoid larvae of the genus Molicola belong to order Trypanorhyncha (De Silva et al., 2017). But due to higher morphological similarity within the genus Molicola, this study was aimed at the molecular identification methods to identify up to the species level and to construct its phylogenetic tree.

The main morphological characteristics of order Trypanorhyncha are, scolex (with two or four bothria) and tentacular apparatus (consists of four tentacles covered with hooks and attached to four bulbs by tentacle sheaths) (Palm et al., 2009). There are about 277 valid Trypanorhyncha species identified so far and new species are being added continuously. Based on a more detailed cladistic analysis, five Trypanorhyncha superfamilies and 15 families were found. The five super families are, Tentacularioidea, Eutetrarhynchoidea, Gymnorhynchoidea, Lacistorhynchoidea, and Otobothrioidea (Palm, 1997).

Taxonomic reports of the genus Molicola indicated the presence of parasitic larvae in teleost muscles and liver. Sunfish (Mola mola) were reportedly infected by Molicola in France, the Mediterranean region, Japan, New Zealand, India, and Canada. Molicola was also reported on muscles of Thyrsites sp. from Holland (Knoff et al., 2004). Molicola horridus possess elongated scolex, four auriculate and elongated bothridia which is curved and apically inclined with roundedged, thick rims that are highly similar to the morphological examination of the Sri Lankan isolate of Molicola sp. reported previously (Knoff et al., 2004; De Silva et al., 2017). But there are other Molicola species (Molicola uncinatus (also called Molicola thyrsitae) (Johns et al., 2009) and Molicola walteri) which share similar morphological characteristics (Palm, 2004), indicating the necessity of 
molecular identification for the determination of species.

In Sri Lanka, very few studies have been conducted on marine capture fish diseases. The presence of cestode and nematode parasites from Sri Lanka was reported as early as 1906 (Shipley and Hornell, 1906). The earliest report of Trypanorhyncha species from Sri Lanka, named Halysiorhynchus microcephalus was isolated from Himantura imbricate (Scaly Whipray) from the Sri Lankan coast (Southwell, 1929). A specimen at the British Museum of Natural History, which was received from Sri Lanka had been identified as another Trypanorhynch larva, Pseudo-gilquinia pillersi (Beveridge et al., 2007). Since there are a number of Trypanorhynch parasites inhabiting various host species, it was a timely necessity to identify the parasitic species present in swordfish muscles.

This study focused on the identification of Molicola plerocercoid larvae up to the species level and to develop a phylogenetic tree to determine its origins. Ribosomal RNA genes of $18 \mathrm{~S}$ and 28S subunits were sequenced for comparative analysis due to their conserved nature during evolution. Based on this study Molicola sp. Sri Lankan isolates found in swordfish enhances the rRNA gene database of Trypanorhyncha parasites.

\section{METHODOLOGY}

\section{Place and Time}

Parasitic samples from the muscles of swordfish (captured from the FAO statistical zone 57 of the Indian Ocean), were obtained from a fish processing factory in Sri Lanka. Samples were collected twice during 2015 and 2016, directly from the fish processing factory and transferred on ice to the Center for
Biotechnology, Department of Zoology, University of Sri Jayewardenapura, Sri Lanka, where all morphological analysis, DNA extraction and polymerase chain reaction (PCR) were performed. PCR products were sent to Microgen, Korea for the Sanger sequencing.

\section{Research Material}

The whitish, thread-like parasitic samples obtained from swordfish muscle were confirmed as Molicola plerocercoid larvae by morphological analysis. To examine the morphology of the parasite using wet mounts, compound light microscope (Olympus, CX22LED, U.S.A.) and microscope slides were utilized and the parasitic samples were fixed in $10 \%$ formalin $1.5 \mathrm{ml}$. Five larvae were confirmed as genus Molicola based on their scolex characteristics and used for genomic DNA extraction. For DNA extraction, reagents mentioned in the methods of Ballinger-Crabtree et al. (1992) were used.

In order to amplify ribosomal subunit genes, primers were designed for $18 \mathrm{~S}$ rRNA (ssrRNA) and 28S rRNA (lsrRNA) gene sequences as shown in Table 1. Primer sequences and PCR protocols for 18S rRNA and 28S rRNA gene amplification were based on Palm et al. (2009) with slight modifications.

PCR reagents such as magnesium chloride $\left(\mathrm{MgCl}_{2}\right)$, deoxyribose nucleotide triphosphate (dNTP), buffer (5x), Taq DNA polymerase (University of Colombo, Sri Lanka) were used to prepare samples for amplification. Thermal cycler (Master cycler personal, Eppendorf, USA) was used to run the PCR. Agarose gel (Promega, USA) was used in gel electrophoresis. ABI sequencer (U.S.A.) was utilized to perform Sanger sequencing at Microgen, Korea. 
Table 1. Primers used to amplify and sequencing of 18S rRNA and 28S rRNA gene segments.

\begin{tabular}{|c|c|c|}
\hline Primer type & Primer ID & Primer sequence \\
\hline \multicolumn{3}{|l|}{ ssrDNA (18S rRNA gene) } \\
\hline Forward primer & ssrDNA F1 & 5`-GCGAATGGCTCATTAAATCAG-3` \\
\hline Reverse primer & ssrDNA R1 & 5`-CTTGTTACGACTTTTACTTCC-3` \\
\hline \multirow[t]{5}{*}{ Internal primers } & $300 \mathrm{~F} 2$ & 5`-AGGGTTCGATTCCGGAG-3` \\
\hline & $600 \mathrm{R}$ & $5^{`}$-ACCGCGGCKGCTGGCACC-3` \\
\hline & $1270 \mathrm{~F}$ & $5^{`}$-ACTTAAAGGAATTGACGG-3` \\
\hline & $930 \mathrm{~F}$ & $5^{`}$-GCATGGAATAATGGAATAGG-3` \\
\hline & $1200 \mathrm{~F}$ & $5^{`}$-CAGGTCTGTGATGCCC-3` \\
\hline \multicolumn{3}{|l|}{ lsrDNA (28S rRNA gene) } \\
\hline Forward primer & lsrDNA F1 & 5`-ACCCGCTGAATTTAAGCATAT-3` \\
\hline Reverse primer & LsrDNA R1 & 5 '-GCTATCCTGAGGGAAACTTCG-3’ \\
\hline \multirow{4}{*}{ Internal primers } & $300 \mathrm{~F}$ & $5^{`}$-CAAGTACCGTGAGGGAAAGTTG-3` \\
\hline & ECD2 & 5`-CTTGGTCCGTGTTTCAAGACGGG-3` \\
\hline & $400 \mathrm{R}$ & 5`-GCAGCTTGACTACACCCG-3` \\
\hline & $1090 \mathrm{~F}$ & 5`-TGAAACACGGACCAAGG-3` \\
\hline
\end{tabular}

\section{Research Design}

Parasitic samples from swordfish muscles were obtained by adhering to the complete randomization method. A total of 20 parasitic samples was obtained for morphological diagnosis and from them, five confirmed Molicola samples (by scolex morphology) were selected for DNA extraction followed by a molecular examination. Each parasitic sample was tested for both 18S rRNA and 28S rRNA genes and sequences were compared for determination of their individual variations and phylogenetic distance.

\section{Work Procedures}

Genomic DNA from five parasites was separated into two sets for the detection of two regions of the ribosomal RNA gene, 18S rRNA and 28S rRNA respectively. PCR reaction was performed using the reagents and amounts as below: Total volume of the PCR product was 25 $\mu \mathrm{l}$. Genomic DNA 2 ng were used from each sample as the template. Double distilled water was added as the negative control. PCR master mix was prepared by adding $1 \mu$ l each from forward and reverse primers, $6 \mu \mathrm{l}$ of magnesium chloride $\left(\mathrm{MgCl}_{2}\right), 1.25 \mu \mathrm{l}$ deoxyribose nucleotide triphosphate (dNTP), buffer (5x) $5 \mu$ l, Taq DNA polymerase (University of Colombo, Sri Lanka) $0.2 \mu$ l into $8.55 \mu$ l of double distilled water to make it $25 \mu$ l of total volume.

The thermocycler was run according to the following conditions: To amplify 18S rRNA gene, initial denaturation at $94^{\circ} \mathrm{C}$ for 2 minutes followed by 40 cycles of $94^{\circ} \mathrm{C}, 30$ seconds, $54^{\circ} \mathrm{C}, 30$ seconds and $72^{\circ} \mathrm{C}, 2$ minutes. For $28 \mathrm{~S}$ rRNA gene amplification, $95^{\circ} \mathrm{C}, 5$ minutes initial denaturation followed by 40 cycles of $95^{\circ} \mathrm{C}, 30$ seconds, $55^{\circ} \mathrm{C}, 30$ seconds and $72^{\circ} \mathrm{C}, 2$ minutes. Both PCRs were finally extended at $72^{\circ} \mathrm{C}$ for 7 minutes before it was kept at $4^{\circ} \mathrm{C}$ until electrophoresis. Final PCR products were observed by one percent (1\%) Agarose gel (Promega, USA) electrophoresis.

All amplicons of 18S rRNA and 28S rRNA genes were sequenced by the Sanger method (ABI sequencer at Microgen, Korea) and sequences were analyzed to confirm the species and constructed the phylogenetic tree.

\section{Data Analysis}

Poor quality bases on both ends of the sequences were trimmed by using Bio Edit software version 7.2.5 (Hall, 1999). Multiple alignments was performed using Clustal $\mathrm{W}$ and assembled by de novo assembly of contigs by CLC Bio genomics work bench version 8.0 (www.clcbio. com). Consensus sequences were compared with the reference sequences 
deposited in National Center for Biotechnology Information (NCBI) by basic local alignment tool (BLAST). Phylogenetic analysis and the taxonomic tree were performed by using Molecular Evolutionary Genetics Analysis (MEGA) version 6.0 (Tamura et al., 2013) neighbour-joining method (Saitou and Nei, 1987).

\section{RESULTS AND DISCUSSION}

Morphological identification of the parasitic larvae found on swordfish muscle was reported previously by our research group as Molicola plerocercoid larvae belong to the Order Trypanorhyncha (De Silva et al., 2017).
The amplicon for 18S rRNA and 28S rRNA gene, obtained by PCR using regionspecific universal primers for trematodes showed electrophoresis band size over $1500 \mathrm{bp}$ which formed the consensus sequences of 18S rRNA and 28S rRNA genes of about $2030 \mathrm{bp}$ and $1500 \mathrm{bp}$ respectively. Based on the sequence analysis of 18S rRNA and 28S rRNA gene, all five isolates from Sri Lanka were aligned to Molicola sp. HP5 (Indonesia) with $99 \%$ and $100 \%$ identity, followed by Molicola thyristes isolate Moli (Australia) and Gymnorhynchus isuri. All three species belonged to the family Gymnorhynchidae (Table 2).

Table 2. Species comparison using NCBI blast of $18 \mathrm{~S}$ and $28 \mathrm{~S}$ rRNA gene sequences of Sri Lankan isolates with species belong to superfamily Gymnorhynchoidea.

\begin{tabular}{|c|c|c|c|c|c|}
\hline \multirow[b]{2}{*}{ Species name } & \multirow[b]{2}{*}{ Family } & \multicolumn{2}{|c|}{ 18S rRNA } & \multicolumn{2}{|c|}{$28 \mathrm{~S}$ rRNA } \\
\hline & & Identity & $\begin{array}{c}\text { NCBI } \\
\text { accession }\end{array}$ & Identity & $\begin{array}{c}\text { NCBI } \\
\text { accession }\end{array}$ \\
\hline Molicola sp. HP5 & Gymnorhynchidae & $99 \%$ & FJ572913 & $100 \%$ & FJ572949 \\
\hline Molicola thyristes & Gymnorhynchidae & $99 \%$ & DQ642908 & $98 \%$ & DQ642746 \\
\hline Gymnorhynchus isuri & Gymnorhynchidae & $98 \%$ & DQ642909 & $97 \%$ & DQ642747 \\
\hline $\begin{array}{l}\text { Pintneriella } \\
\text { musculicola }\end{array}$ & Rhopalothylacidae & $98 \%$ & FJ572912 & $96 \%$ & FJ572948 \\
\hline $\begin{array}{l}\text { Chimaerarhynchus } \\
\text { rougetae }\end{array}$ & Gymnorhynchidae & $95 \%$ & DQ642906 & $93 \%$ & DQ642744 \\
\hline Vittirhynchus squali & Gilquiniidae & $95 \%$ & DQ642905 & $93 \%$ & DQ642743 \\
\hline $\begin{array}{l}\text { Sagittirhynchus } \\
\text { aculeatus }\end{array}$ & Gilquiniidae & $95 \%$ & DQ642907 & $93 \%$ & DQ642745 \\
\hline Gilquinea robertsoni & Gilquiniidae & $95 \%$ & FJ572910 & $93 \%$ & FJ572944 \\
\hline $\begin{array}{l}\text { Aporhynchus } \\
\text { norvegicus }\end{array}$ & Aporhynchidae & $95 \%$ & FJ572911 & $93 \%$ & FJ572947 \\
\hline
\end{tabular}

This clearly confirmed that the plerocercoid larvae isolated from swordfish from Sri Lanka (Indian ocean) belonged to the genus Molicola, family Gymnorhynchidae. There were point mutations and insertions in $18 \mathrm{~S}$ and $28 \mathrm{~S}$ rRNA gene sequences possibly due to the individual variations. The evolutionary distance between the sequences of five isolates was not significantly different ( $p$ $>0.05$ ). Therefore, all the parasitic larvae isolated from swordfish in this study belong to the same species.

Though the analysis of 18S rRNA and $28 \mathrm{~S}$ rRNA gene sequences were performed in five individual parasitic samples, there were less than ten nucleotide variations found (more than 95\% identity) indicating that they all belong to the same species. The significant identity of Sri Lankan isolates with Molicola sp. Hp5 from Indonesia obtained from Taractes rubescens, suggests that swordfish captured near the Sri Lankan coast might have migrated via Indonesian coasts. Furthermore, both T. rubescens and swordfish are pelagic fish that shows similar feeding patterns (Scott and Tibbo, 1968; Gòmez-Morales et al., 2008), justifying the possible entry of Molicola larvae through their food chain. The other species of close identity with Sri Lankan 
isolates was Molicola thyristes isolated from Australia in Thyrsites atun. It is also an intermediate host of Molicola sp. which feeds on pelagic crustaceans (Nakamura and Parin, 1993).

Phylogenetic analysis of $18 \mathrm{~S}$ rRNA and 28S rRNA sequences of Molicola Sri Lankan isolates were compared with 20 Trypanorhyncha species belonged to different families. Based on the phylogenetic analysis, the highest significance with Molicola sp. HP5 isolate from Indonesia was observed and Sri Lankan isolates shared the common ancestor with members from the Gymnorhynchidae family (Figure 1). The comparison of both phylogenetic trees showed similarity in 18S rRNA and 28S rRNA genes. Accordingly, it confirms the morphologically recognized genus of the parasite. Nucleotide sequences of $18 \mathrm{~S}$ and $28 \mathrm{~S}$ ribosomal subunit gene of Molicola sp.
Currently, in the NCBI database only two Molicola species 18S and 28S rRNA gene sequences were available for comparison. Therefore, our results were submitted as Molicola sp. SL 01 to 05 . The country of origin, Sri Lanka was stand by 'SL' and one to five indicates the individual plerocercoid larval isolates. The Sri Lankan isolates identified from this study were deposited at NCBI GenBank with the accession numbers for 18S rRNA partial gene sequences starting from KX712332 to KX 712336 and for 28S rRNA partial gene sequences from KX712337 to KX712341. This is the first study on rRNA genes of Molicola sp. infested in the muscles of swordfish captured from the Sri Lankan coast to the best of our knowledge. Further studies on other Molicola species are needed to develop a better sequence comparison and speciation of the genus Molicola.

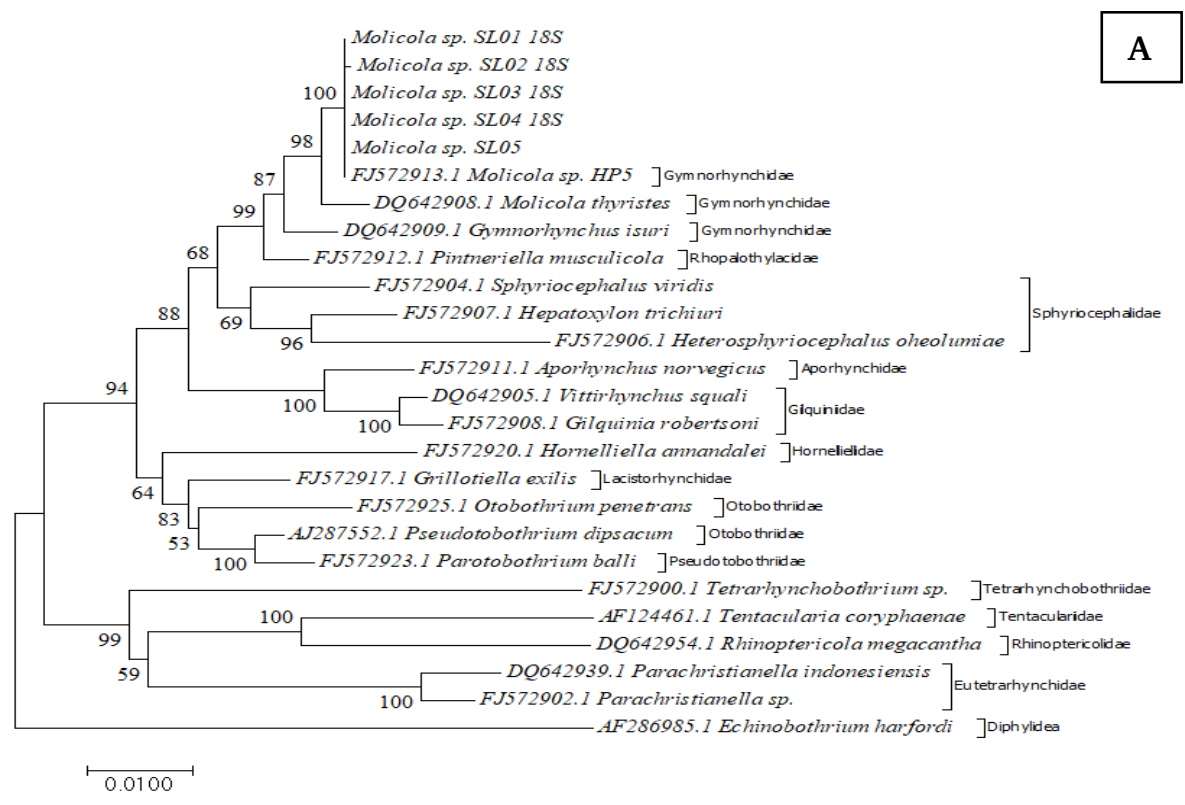




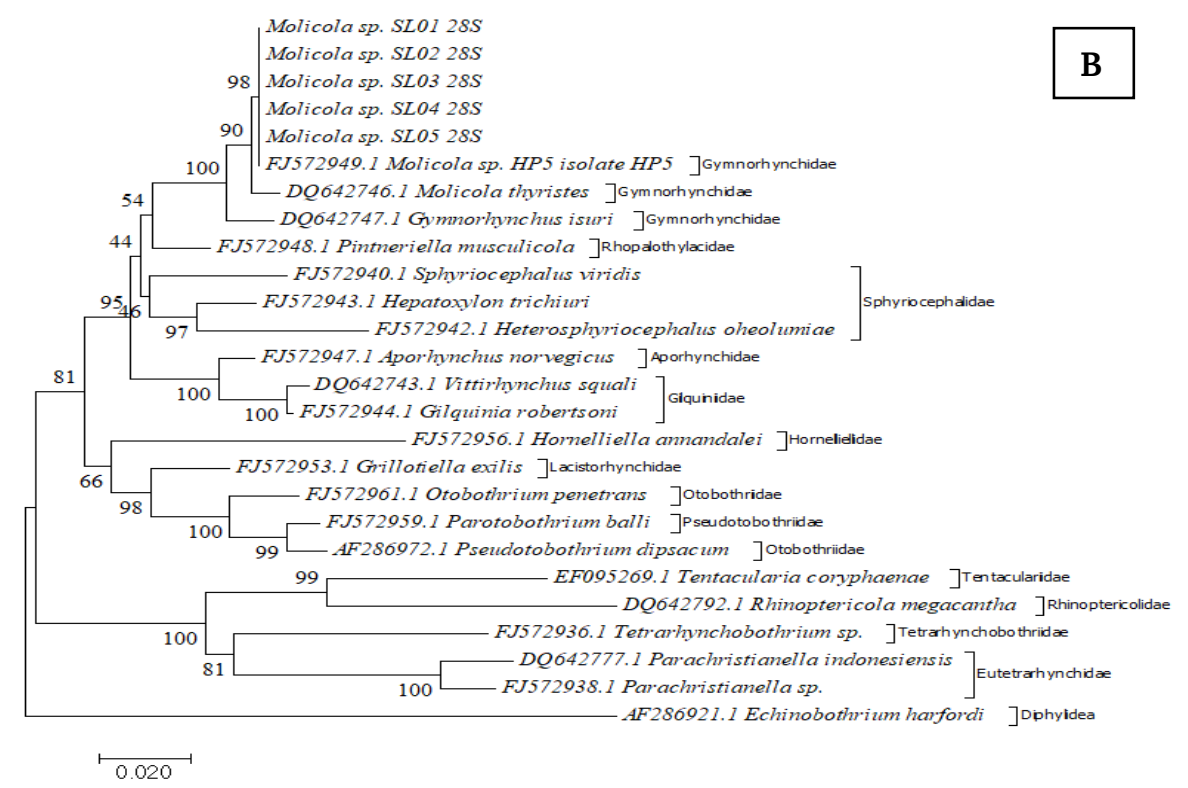

Figure 1. Evolutionary relationships of Molicola Sri Lankan isolates with other species belong to different taxonomic families of order Trypanorhyncha, obtained by Neighbor-joining method using (A) 18S rRNA and (B) 28S rRNA gene sequences. Scientific names of the species and their NCBI accession numbers were written at respective nodes and the branch lengths indicate the evolutionary distance drawn to a scale bar of 0.01 for $18 \mathrm{~S}$ and 0.02 for $28 \mathrm{~S}$ rRNA gene. E. harfordi belong to the order Diphyllidea was used as an outgroup.

It is mandatory to perform fish quality checks before exporting to other countries and the difficulty arose when both Trypanorhyncha and Anisakis species look alike grossly in color and consistency (Muscolino et al., 2012). Although Molicola is not a zoonotic parasite as Anisakis studies on mice have shown anaphylaxis due to Molicola horridus allergens (Gomez-Morales et al., 2008). However, the chance of allergic reactions to occur in consumers by using frozen swordfish slices is very low, but the parasitized flesh reduces the consumer preference (Muscolino et al. 2012). Hence this method can be used for confirmatory and differential diagnosis of Trypanorhyncha parasites from other fish parasites.

\section{CONCLUSION}

The whitish parasite isolated from swordfish muscles belonged to the genus Molicola, order Trypanorhyncha. Molecular phylogenetic analysis and sequence comparison of $18 \mathrm{~S}$ and $28 \mathrm{~S}$ ribosomal subunit genes revealed a higher similarity to Molocola sp. HP5 from Indonesia. This is the first record of molecular analysis of ribosomal subunit genes in Molicola species isolated from swordfish captured near the Sri Lankan coast.

\section{ACKNOWLEDGMENT}

The authors would like to acknowledge the staff members of the Center for Biotechnology, Department of Zoology, University of Sri Jayewardenapura, Sri Lanka.

\section{REFERENCES}

Ballinger-Crabtree, M.E., Black, W.C. and Miller B.R., 1992. Use of genetic polymorphisms detected by the random-amplified polymorphic DNA polymerase chain reaction (RAPDPCR) for differentiation and identification of Aedes aegypti subspecies and populations. The American Journal of Tropical Medicine and Hygiene, 47(6), 
pp.893-901. https://doi.org/10.426 9/ajtmh.1992.47.893

Beveridge, I., Chauvet, C. and Justine, J.L., $2007 . \quad$ Redescription of Pseudogilquinia pillersi (Southwell, 1929) (Cestoda, Trypanorhyncha) from serranid and lethrinid fishes from New Caledonia and Australia. Acta Parasitologica, 52(3), pp.213218. https://doi.org/10.2478/s116 86-007-0029-9

Castro-Pampillón, J.A., RodríguezDomínguez, H., Soto-Búa, M., Mejuto-García, J., Arias Fernández, C. and García-Estévez, J.M., 2002. Parasites of swordfish from the Gulf of Guinea. Journal of Parasitology, 88(1), pp.188-189. https://doi.org/ 10.1645/0022-3395(2002)088[018 8:POSFTG]2.0.CO;2

CLC Bio Genomics Workbench version 8.0 (http://www.clcbio.com), Accessed on $2^{\text {nd }}$ May 2015.

De Silva, D.P.N., Fernando, H.S.D., Ranatunga, R.R.M.K.P. and De Silva, B.G.D.N.K., 2017. First record of plerocercoid larvae belong to the order Trypanorhyncha (Diesing 1863) isolated from swordfish (Xiphias gladius, Linnaeus 1758) captured off Sri Lanka. Sri Lanka Journal of Aquatic Sciences, 22(1), p.67-70. https://doi.org/10.4038/ sljas.v22i1.7518

Food and Agriculture Organization of the United Nations, Xiphias gladius. Website. http://www.fao.org/fisher y/species/2503/en. Accessed on $12^{\text {th }}$ July 2019.

Garcia, A., Mattiucci, S., Damiano, S., Santos, M.N. and Nascetti, G., 2011. Metazoan parasites of swordfish, Xiphias gladius (Pisces: Xiphiidae) from the Atlantic Ocean: implications for host stock identification. ICES Journal of Marine Science, 68(1), pp.175-182. https://doi.org/10.1093/icesjms/fs q147

Gòmez-Morales, M.A., Ludovisi, A., Giuffra, E., Manfredi, M.T., Piccolo, G. and Pozio, E., 2008. Allergenic activity of Molicola horridus (Cestoda, Trypanorhyncha), a cosmopolitan fish parasite, in a mouse model. Veterinary Parasitology, 157(3-4), pp.314-320. https://doi.org/10.1016/j.vetpar.2 008.07.010

Hall, A.T., 1999. BioEdit: a user-friendly biological sequence alignment editor and analysis program for windows 95/98/NT. Nucleic Acids Symposium Series, 41, pp.95-98. http://www.academia.edu/downlo ad/29520866/1999hall1.pdf

Hogans, W.E., Brattey, J., Uhazy, L.S. and Hurley, P.C.F., 1983. Helminth parasites of swordfish (Xiphias gladius L.) from the northwest Atlantic Ocean. Journal of Parasitology, 69(6), pp.1178-1179.

Hogans, W.E., Brattey, J. and Hurlbut, T.R., 1985. Pennella filosa and Pennella instructa (Copepoda, Pennellidae) on swordfish (Xiphias gladius L.) from the northwest Atlantic Ocean. Journal of Parasitology, 71(1), pp.111-112.

IUCN Red List of Threatened Species, Xiphias gladius. Website: http:// www.iucnredlist.org/details/23148 $/ 0$. Accessed on $5^{\text {th }}$ May 2019.

Johns, P., Newman, L.J., Holleman, J.J., Dawson, E.W., Sterrer, W., Allison, F.R., Diggles, B.K., Andrews, J.R.H., Hine, P.M., McKenna, P.B. and Poulin, R., 2009. Phylum Platyhelminthes: flatworms, tapeworms, flukes. In: New Zealand inventory of biodiversity: 1. Kingdom Animalia: Radiata, Lophotrochozoa, Deuterostomia (ed. by D.P. Gordon), Canterbury University Press, Christchurch, New Zealand. pp.102128.

Knoff, M., Clemente, S.C. de S., Pinto, R.M., Lanfredi, R.M. and Gomes, D.C., 2004. Taxonomic reports of Otobothrioidea (Eucestoda, Trypanorhyncha) from elasmobranch fishes of the Southern coast of Brazil. Memorias do Instituto Oswaldo Cruz, 99(1), pp.31-36. 
https://doi.org/10.1590/S0074-

02762004000100006

Muscolino, D., Giarratana, F., Giuffrida, A. and Panebianco, A., 2012. Inspective investigation on swordfish (Xiphias gladius) frozen slices of commerce: anatomicalhistopatological findings. Czech Journal of Food Sciences, 30, pp.206210. https://doi.org/10.17221/151 /2011-CJFS

Nakamura, I. and Parin, N.V., 1993. Snake mackerels and cutlassfishes of the world (families Gempylidae and Trichiuridae): An annotated and illustrated catalogue of the snake mackerels, snoeks, escolars, gemfishes, sackfishes, domine, oilfish, cutlassfishes, scabbardfishes, hairtails and frostfishes known to date. Food and Agriculture Organization (FAO), 125(15), p.136.

Palm, H.W., 1997. An alternative classification of trypanorhynch cestodes considering the tentacular armature as being of limited importance. Systematic Parasitology, 37, pp.81-92. https://doi.org/10.10 23/A:1005765126294

Palm, H.W., 2004. The Trypanorhyncha Diesing, 1863. SPL-IPB Press, Bogor Agricultural University, West Java, Indonesia. p. 710.

Palm, H.W. and Caira, J.N., 2008. Host specificity of adult versus larval cestodes of the elasmobranch tapeworm order Trypanorhyncha. International Journal for Parasitology, 38(3-4), pp.381-388. https://doi.org/10.1016/j.ijpara.20 07.08.011

Palm, H.W., Waeschenbach, A., Olson, P.D. and Littlewood, D.T.J., 2009. Molecular phylogeny and evolution of the Trypanorhyncha Diesing, 1863 (Platyhelminthes: Cestoda). Molecular Phylogenetics and Evolution, 52(2), pp.351-367. https://doi.org/10.1016/j.ympev.2 009.01.019
Saitou, N. and Nei, M., 1987. The neighbor-joining method: a new method for reconstructing phylogenetic trees. Molecular Biology and Evolution, 4(4), pp.406425.

https://doi.org/10.1093/oxfordjour nals.molbev.a040454

Schaperclaus, W., 1992. Causes, development and prevention of fish diseases. Fish diseases, 5th edn. AA Balkema Publisher, Rotterdam, pp.342.

Scott, W.B. and Tibbo, S.N., 1968. Food and feeding habits of Swordfish, Xiphias gladius, in the Western North Atlantic. Journal of the Fisheries Research Board of Canada, 25(5), pp.903-919. https://doi.org/ 10.1139/f68-084

Shipley, A.E. and Hornell, J., 1906. Report on the cestode and nematode parasites from Ceylon. Report to the Government of Ceylon on the pearl oyster fisheries of the Gulf of Mannar. Royal Society, London. Part V, pp.43-96.

Southwell, T., 1929. A monograph on cestodes of the order Trypanorhyncha from Ceylon and India. Part I. Ceylon Journal of Science, 15, pp.169-312.

Statistics, Ministry of Fisheries and Aquatic Resource Development, Sri Lanka. Website. http://www.fisher ies.gov.lk/content.php?cnid=ststc, Accessed on $25^{\text {th }}$ October 2019.

Tamura, K., Stecher, G., Peterson, D., Filipski, A. and Kumar, S., 2013. MEGA 6: Molecular evolutionary genetics analysis version 6.0. Molecular Biology and Evolution, 30(12), pp.2725-2729. https://doi. org/10.1093/molbev/mst197

Williams, Jr. E.H. and Bunkley-Williams, L., 1996. Parasites of offshore big game fishes of Puerto Rico and the Western Atlantic. Sport fish Disease Project, University of Puerto Rico, PR. pp.330-332. 